\title{
PENILAIAN RANAH AFEKTIF PESERTA DIDK DENGAN MENGGUNAKAN MODUL BERORIENTASI LITERASI SAINS MATERI KOMPONEN EKOSISTEM
}

\author{
Monica Rahmawati ${ }^{1}$, Agus Sujarwanta ${ }^{2}$, Handoko Santoso ${ }^{3}$ \\ ${ }^{1}$ SMKN Sekampung Lampung Timur \\ ${ }^{23}$ Program Pascasarjana Pendidikan Biologi, Universitas Muhammadiyah Metro \\ Momomonica.24@gmail.com ${ }^{1}$, agussujarwanta@ymail.com ${ }^{2}$,handoko.umm@gmail.com²
}

\begin{abstract}
Abstrak : Pengembangan Modul Biologi berorientasi literasi sains dibuat berdasarkan masalah yang ada di SMA Negeri 2 Sekampung yaitu bahan ajar yang digunakan tidak sesuai dengan latar belakang sekolah dan hasil belajar pada materi Komponen Ekosistem perlu adanya perubahan penyampaian materi tersebut secara literasi sains. Berdasarkan masalah tersebut, maka penelitian ini bertujuan untuk menghasilkan modul biologi berorientasi literasi sains pada materi komponen ekosistem dan efektif meningkatkan pemahaman dan kesadaran peserta didik kelas X. Pengembangan modul ini menggunakan motode pengembangan Research and Development model pengembangan ADDIE . Subjek penilaian yaitu ahli materi, ahli media, ahli bahasa, praktisi pendidikan, dan peserta didik kelas X. Instrumen yang digunakan berupa angket dan tes hasil belajar. Hasil penelitian ini adalah tersusun modul Biologi berorientsi literasi sains pada materi komponen ekosistem untuk peserta didik kelas X. Berdasarkan hasil penilaian kualitas modul diperoleh kategori baik dan efektif dalam meningkatkan kesadaran dan pemahaman peserta didik. Sehingga dapat disimpulkan bahwa modul biologi yang dikembangkan layak digunakan sebagai bahan ajar mandiri untuk peserta didik kelas X.
\end{abstract}

Kata Kunci : modul,berorientasi literasi sains, afektif

\begin{abstract}
Development of Biology Module oriented science literacy is based on the problems that exist in SMA Negeri 2 Sekampung namely teaching materials used are not in accordance with school background and learning outcomes in the Ecosystem Components material needs to change the delivery of these materials in scientific literacy. Based on these problems, this study aims to produce biology modules oriented towards science literacy on ecosystem component materials and effectively improve the understanding and awareness of class $X$ students. The development of this module uses the development model of the Research and Development ADDIE development model. Subjects of assessment are material experts, media experts, linguists, education practitioners, and class X students. The instruments used were questionnaires and test results for learning. The results of this study are arranged a Biology module oriented in science literacy on ecosystem component material for class $X$ students. Based on the results of the module quality assessment, it is obtained a good and effective category in increasing the awareness and understanding of students. So it can be concluded that the biology module developed is suitable to be used as an independent teaching material for grade X students. Keywords : module, oriented scientific literacy, affective
\end{abstract}

\section{How to Cite}

Rahmawati, Monica, Agus Sujarwanta, Handoko Santoso. 2021. Penilaian Ranah Afektif Peserta Didk Dengan Menggunakan Modul Berorientasi Literasi Sains Materi Komponen Ekosistem. Biolova. 22 .114 -121 . 
Literasi sains atau melek sains menurut Yuliati (2017:22) dapat diartikan sebagai kemampuan untuk memahami, mengkomunikasikan (baik lisan maupun tulisan), serta menerapkan kemampuan sains untuk memecahkan masalah sehingga memiliki sikap dan kepekaan yang tinggi terhadap diri dan lingkungannya. Oleh karena itu, kemampuan literasi sains dianggap penting ditanamkan dalam diri peserta didik. Literasi ilmiah mencakup literasi dalam sains dan teknologi. Ada banyak definisi ilmiah melek huruf seperti itu adalah subjek yang sangat komprehensif dengan sejarah yang sangat panjang. Murat (2015:143).

Modul sering dikaitkan dengan aktivitas pembelajaran mandiri. Modul merupakan bahan ajar yang berpusat kepada peserta didik untuk dapat belajar secara mandiri dan mencapai tujuan pembelajaran. Nisa (2014:23-24) menyatakan bahwa pembelajaran menggunakan modul memiliki kegunaan diantaranya: a). Memperjelas dan mempermudah penyajian pesan agar tidak terlalu bersifat verbal, b). Mengatasi keterbatasan waktu, ruang, dan daya indera, baik peserta didik maupun guru, c). Modul dapat digunakan secara tepat dan bervariasi untuk meningkatkan motivasi dan gairah belajar, d). dengembangkan kemampuan peserta didik dalam berinteraksi dengan lingkungan dan sumber belajar yang memungkinkan terciptanya belajar mandiri sesuai kemampuan dan minatnya, e). Memungkinkan peserta didik dapat mengukur atau mengevaluasi sendiri hasil belajarnya.

Sedangkan menurut Depdiknas, 2008 (dalam Satria, 2017:12) fungsi modul ialah sebagai bahan belajar yang digunakan dalam kegiatan pembelajaran peserta didik, membuat proses pembelajaran lebih terarah dan sistematis, memberikan petunjuk belajar sehingga mampu menguasai kompetensi yang dituntut oleh kegiatan pembelajaran yang diikutinya.

Bahan ajar dikembangkan berupa modul. Karena modul merupakan bahan ajar yang disusun secara sistematis dan dapat dipelajari secara mandiri oleh peserta didik sesuai dengan kecepatan belajar masing-masing individu, dengan kata lain modul memiliki lima karakteristik yaitu self instruction, self contained, stand alone, adaptive, dan user friendly (Prastowo dalam Sawitri, dkk, 2014:411). Modul yang digunakan selama ini hanya mencantumkan aspek pengetahuan saja belum mengikut sertakan literasi sains, untuk literasi sains sendiri banyak berbagai aspek yang harus dicantumkan yaitu aspek kontek, konten, kompetensi, dan sikap. Kurikulum 13 saat ini dilihat dari silabus mata pelajaran Biologi bahwa dalam proses mengajar baik bahan ajar maupun buku harus menerapkan literasi sains, sekolah juga menerapkan gerakan literasi. Literasi sains dianggap penting dalam proses pembelajaran karena tujuan pendidikan sains adalah meningkatkan kompetensi peserta didik untuk dapat memenuhi kebutuhan hidupnya dalam berbagai situasi termasuk dalam menghadapi berbagai tantangan hidup di era global. Dengan literasi sains, peserta didik akan mampu belajar lebih lanjut dan hidup di masyarakat modern yang saat ini banyak dipengaruhi oleh perkembangan sains dan teknologi. Adapun tujuan dari penelitian ini 
adalah mengetahui manfaat modul literasi sains serta penilaian pada ranah kognitif peserta didik.

\section{METODE}

Metode yang digunakan yaitu pengembangan ADDIE dengan terdiri dari lima tahap yaitu Analysis (Analisis), Design (Desain), Development (Pengembangan), Implementation (Implementasi), dan Evaluation (Evaluasi). Subjek penilaian yang menilai modul terdiri dari ahli materi, ahli media, ahli bahasa, praktisi pendidikan (guru mata pelajaran biologi), dan peserta didik kelas X SMA yang terdiri dari 26 orang. Jenis data yang diperoleh dalam penelitian berupa data kuantitatif yang diperoleh dari hasil penilaian modul dan hasil belajar peserta didik. Selain itu, juga didapatkan data kualitatif dari saran revisi dari ahli, praktisi pendidikan dan peserta didik. Metode pengumpulan data dalam penelitian ini yaitu menggunakan angket yang diujikan kepada ahli, praktisi pendidikan, dan peserta didik.
Data pengembangan modul berupa angket hasil validasi produk yang

dianalisis menggunakan skala Likert. Setelah data ditabulasi, maka selanjutnya data tersebut dihitung persentase kelayakan dan keterbacaannya sesuai dengan pernyataan yang telah diberikan, dalam perhitungan ini menggunakan rumus:

$\mathrm{P}(\mathrm{s})=\frac{S}{N} \times 100 \%$

Keterangan:

$\mathrm{P}(\mathrm{s})=$ Persentase sub variabel

$\mathrm{S}=$ Jumlah skor tiap sub variabel

$\mathrm{N}$ = Jumlah skor maksimum (Ali dalam Kristiningrum, 2007:40).

Setelah penilaian angket selesai dihitung persentasenya, maka tahap selanjutnya yaitu menafsirkan angka yang didapat dari hasil perhitungan, hal ini bertujuan untuk mengetahui tingkat kelayakan dan keterbacaan modul yang telah dikembangkan.

\section{HASIL DAN PEMBAHASAN}

Produk ini sudah divalidasi oleh validator yaitu mata pelajaran. Adapun hasil validasi sebagai ahli materi, ahli desain, keterbacaan, serta guru berikut:

Tabel 1. Konversi Tingkat Pencapaian dengan Skala 5

\begin{tabular}{|l|l|l|l|}
\hline No & $\begin{array}{c}\text { Interval rata-rata } \\
\text { penilaian ahli (\%) }\end{array}$ & \multicolumn{1}{|c|}{ Kriteria untuk ahli } & \multicolumn{1}{|c|}{$\begin{array}{c}\text { Kriteria untuk } \\
\text { peserta didik }\end{array}$} \\
\hline 1 & $80,01 \leq$ skor $\leq 100,00$ & Sangat Layak & Sangat Baik \\
\hline 2 & $60,01 \leq$ skor $\leq 80,00$ & Layak & Baik \\
\hline 3 & $40,01 \leq$ skor $\leq 60,00$ & Cukup Layak & Cukup Baik \\
\hline 4 & $20,01 \leq$ șkor $\leq 40,00$ & Tidak Layak & Tidak Baik Baik \\
\hline 5 & $0,00 \leq$ skor $\leq 20,00$ & Sangat Tidak Layak & Sangat Tidak Baik \\
\hline
\end{tabular}

Sumber: Ali (dalam Kristiningrum, 2007:41) 
Tabel 2. Validasi Ahli materi

\begin{tabular}{|l|l|c|c|c|}
\hline No & \multicolumn{1}{|c|}{ Kriteria Penilaian } & Nilai & Persentase & Kategori \\
\hline 1. & $\begin{array}{l}\text { Materi yang dikembangkan mencakup } \\
\text { dalam kurikulum yang berlaku }\end{array}$ & 4 & $80 \%$ & Layak \\
\hline 2. & $\begin{array}{l}\text { Materi sesuai dengan tujuan pembelajaran } \\
\text { dan indikator pencapaian }\end{array}$ & 4 & $80 \%$ & Layak \\
\hline 3. & $\begin{array}{l}\text { Penjabaran materi dalam modul } \\
\text { membantu siswa untuk mencapai } \\
\text { kompetensi dasar }\end{array}$ & 4 & $80 \%$ & Layak \\
\hline 4. & $\begin{array}{l}\text { Materi spesifik, akurat, jelas, dan sesuai } \\
\text { dengan kebutuhan bahan ajar }\end{array}$ & 4 & $80 \%$ & Layak \\
\hline 5. & $\begin{array}{l}\text { Kesesuaian konsep dalam modul dengan } \\
\text { konsep yang dikemukakan oleh ahli } \\
\text { Biologi }\end{array}$ & 4 & $80 \%$ & Layak \\
\hline 6. & $\begin{array}{l}\text { Kesesuaian materi dengan nilai moral dan } \\
\text { nilai sosial }\end{array}$ & 4 & $80 \%$ & Layak \\
\hline 7. & $\begin{array}{l}\text { Menekankan pengalaman langsung } \\
\text { Mengembangkan keterampilan proses } \\
\text { untuk menemukan hal baru }\end{array}$ & 4 & $80 \%$ & $100 \%$ \\
\hline 9. & $\begin{array}{l}\text { Keseimbangan penjabaran materi, } \\
\text { pengembangan makna dan pemahaman, } \\
\text { pemecahan masalah, pengembangan } \\
\text { proses, latihan dan praktik, tes } \\
\text { keterampilan, maupun pemahaman }\end{array}$ & 5 & $100 \%$ & $\begin{array}{l}\text { Sangat } \\
\text { Layak }\end{array}$ \\
\hline 10. & $\begin{array}{l}\text { Evaluasi/ uji kompetensi/Diskusi yang } \\
\text { disajikan dalam modul dapat mengukur } \\
\text { kemampuan kognitif, afektif, dan } \\
\text { psikomotor peserta didik }\end{array}$ & 4 & $80 \%$ & Layak \\
\hline Rata--rata Keseluruhan Kriteria & 4,2 & $84 \%$ & $\begin{array}{l}\text { Sangat } \\
\text { Layak }\end{array}$ \\
\hline
\end{tabular}

Berdasarkan hasil penilaian modul oleh ahli persentase sebesar $84 \%$ termasuk ke dalam materi dapat dilihat bahwa skor rata-rata kategori "sangat baik".

keseluruhan kriteria sebesar 4,2 dengan

Tabel 3. Hasil Penilaian Ahli Desain

\begin{tabular}{|c|l|c|c|c|}
\hline No & \multicolumn{1}{|c|}{ Kriteria Penilaian } & Nilai & Persentase & Kategori \\
\hline 1 & $\begin{array}{l}\text { Kesesuaian antara jenis font dan } \\
\text { jarak spasi }\end{array}$ & 4 & $80 \%$ & Layak \\
\hline 2 & $\begin{array}{l}\text { Bahasa yang digunakan mudah } \\
\text { dipaham }\end{array}$ & 4 & $80 \%$ & Layak \\
\hline 3 & $\begin{array}{l}\text { Bahasa yang digunakan sesuai } \\
\text { dengan kaidah bahasa yang benar }\end{array}$ & 4 & $100 \%$ & Layak \\
\hline 4 & Kesesuaian gambar dengan materi & 5 & $100 \%$ & Sangat Layak \\
\hline 5 & Gambar menarik perhatian siswa & 5 & $100 \%$ & Sangat Layak \\
\hline 6 & $\begin{array}{l}\text { Tata letak dan ukuran gambar } \\
\text { sesuai }\end{array}$ & 4 & $80 \%$ & Layak \\
\hline 7 & Warna gambar/font jelas & 4 & $80 \%$ & Layak \\
\hline
\end{tabular}




\begin{tabular}{|c|c|c|c|c|}
\hline 8 & Warna/font sesuai & 4 & $80 \%$ & Layak \\
\hline 9 & $\begin{array}{l}\text { Penyajian materi dalam modul } \\
\text { sistematis, logis, sederhana, jelas, } \\
\text { dan runtut }\end{array}$ & 4 & $80 \%$ & Layak \\
\hline 10 & $\begin{array}{l}\text { Menunjang keterlibatan siswa untuk } \\
\text { aktif mengemukakan dan berbagi } \\
\text { ide }\end{array}$ & 4 & $80 \%$ & Layak \\
\hline 11 & $\begin{array}{l}\text { Mengaitkan suatu konsep dengan } \\
\text { konsep yang lainnya dalam } \\
\text { menjelaskan fenomena }\end{array}$ & 4 & $80 \%$ & Layak \\
\hline 12 & $\begin{array}{l}\text { Kegiatan yang terdapat dalam } \\
\text { modul mendorong siswa untuk } \\
\text { mengalami secara langsung (studi } \\
\text { lapangan) }\end{array}$ & 4 & $80 \%$ & Layak \\
\hline 13 & $\begin{array}{l}\text { Mengajak siswa aktif dalam } \\
\text { pembelajaran }\end{array}$ & 5 & $100 \%$ & Sangat Layak \\
\hline 14 & $\begin{array}{l}\text { Desain modul pembelajaran } \\
\text { (konsisten, terformat, terorganisasi, } \\
\text { dan memiliki daya tarik) }\end{array}$ & 5 & $100 \%$ & Sangat Layak \\
\hline 15 & $\begin{array}{l}\text { Judul, gambar, dan keterangan } \\
\text { gambar dapat dipahami }\end{array}$ & 4 & $80 \%$ & Layak \\
\hline 16 & $\begin{array}{l}\text { Mengembangkan berbagai cara } \\
\text { untuk menyajikan informasi (peta } \\
\text { konsep, uraian materi, pengetahuan } \\
\text { sains, rangkuman dan glosarium) } \\
\end{array}$ & 4 & $80 \%$ & Layak \\
\hline 17 & $\begin{array}{l}\text { Ilustrasi sampul menggambarkan } \\
\text { materi yang disampaikan }\end{array}$ & 4 & $80 \%$ & Layak \\
\hline 18 & $\begin{array}{l}\text { Isi modul Biologi ini sesuai dengan } \\
\text { isi modul ideal }\end{array}$ & 4 & $80 \%$ & Layak \\
\hline 19 & $\begin{array}{l}\text { Saduran, cuplikan, dan kutipan } \\
\text { mencantumkan sumbernya dengan } \\
\text { jelas. }\end{array}$ & 4 & $80 \%$ & Layak \\
\hline 20 & $\begin{array}{l}\text { Gambar, baik gambar nyata maupun } \\
\text { animasi, grafik, dan data hasil } \\
\text { kutipan harus mencatumkan } \\
\text { sumbernya. }\end{array}$ & 5 & $100 \%$ & Sangat Layak \\
\hline \multicolumn{2}{|c|}{ Rata--rata Keseluruhan Kriteria } & 4,25 & $85 \%$ & Sangat Layak \\
\hline
\end{tabular}

Berdasarkan hasil validasi ahli desain di atas dapat dilihat bahwa persentase yang diperoleh yaitu sebesar $85 \%$ dengan rata-rata skor 4,25 maka modul biologi yang dikembangkan termasuk ke dalam kategori "sangat baik" dari segi desain.

Tabel 4. Hasil Penilaian Uji Bahasa

\begin{tabular}{|c|l|c|c|c|}
\hline No & \multicolumn{1}{|c|}{ Kriteria Penilaian } & Nilai & Presentase & Kategori \\
\hline 1 & $\begin{array}{l}\text { Bahasa yang digunakan sederhana, lugas, } \\
\text { dan mudah dibaca dan dipahami }\end{array}$ & 5 & $100 \%$ & Sangat Layak \\
\hline 2 & Informasi yang disajikan jelas & 5 & $100 \%$ & Sangat Layak \\
\hline
\end{tabular}




\begin{tabular}{|c|l|c|c|c|}
\hline 3 & $\begin{array}{l}\text { Penggunaan bahasa Indonesia yang } \\
\text { sesuai dengan aturan Ejaan Bahasa } \\
\text { Indonesia (EBI) }\end{array}$ & 4 & $80 \%$ & Layak \\
\hline 4 & $\begin{array}{l}\text { Kalimat yang digunakan komunikatif dan } \\
\text { interaktif }\end{array}$ & 4 & $80 \%$ & Layak \\
\hline 5 & $\begin{array}{l}\text { Kejelasan tujuan pembelajaran (indikator } \\
\text { yang dicapai) }\end{array}$ & 5 & $100 \%$ & Sangat Layak \\
\hline 6 & $\begin{array}{l}\text { Urutan penyajian sesuai } \\
\text { Isi modul memotivasi dan menarik } \\
\text { peserta didik dari segi bahasa }\end{array}$ & 5 & $100 \%$ & Sangat Layak \\
\hline 8 & $\begin{array}{l}\text { Bahasa yang digunakan sesuai dengan } \\
\text { perkembangan peserta didik }\end{array}$ & 4 & $80 \%$ & Sangat Layak \\
\hline 9 & $\begin{array}{l}\text { Bahasa yang digunakan mengembangkan } \\
\text { kemampuan berpikir siswa dalam } \\
\text { memahami konsep }\end{array}$ & 4 & $80 \%$ & Layak \\
\hline 10 & $\begin{array}{l}\text { Informasi (bahan, latihan, dan soal) yang } \\
\text { disajikan lengkap }\end{array}$ & 5 & $100 \%$ & Sangat Layak \\
\hline Rata--rata Keseluruhan Kriteria & 4,6 & $92 \%$ & Sangat Layak \\
\hline
\end{tabular}

Berdasarkan hasil penilaian ahli bahasa di atas dapat dilihat bahwa keseluruhan kriteria

penilaian mendapatkan skor rata-rata 4,6 termasuk dalam kategori "sangat layak" dengan persentase $92 \%$.

Tabel 5. Hasil Penilaian Praktisi Pendidikan

\begin{tabular}{llccc}
\hline No & Aspek & Nilai & Persentase & Kategori \\
\hline 1 & Isi modul & 4,5 & $90 \%$ & Sangat baik \\
\hline 2 & Materi & 4,5 & $90 \%$ & Sangat baik \\
\hline 3 & Evaluasi & 4,3 & $86 \%$ & Sangat baik \\
\hline 4 & Penyajian & 4,4 & $94 \%$ & Sangat baik \\
\hline 5 & Bahasa/keterbacaan & 4,4 & $88 \%$ & Sangat Baik \\
\hline 6 & Tampilan modul & 5 & $100 \%$ & Sangat baik \\
\hline Rata-rata keseluruhan kriteria & 4,51 & $90,2 \%$ & Sangat baik \\
\hline
\end{tabular}

Berdasarkan hasil validasi praktisi rata-rata keseluruhan kriteria sebesar 4,51 pendidikan yang dilakukan oleh guru mata dengan persentase sebesar 90,2\% dan termasuk pelajaran biologi didapatkan hasil bahwa skor ke dalam kategori "sangat baik".

Tabel 6. Hasil Penilaian Peserta Didik

\begin{tabular}{cccc}
\hline $\begin{array}{c}\text { Jumlah peserta } \\
\text { didik }\end{array}$ & $\begin{array}{c}\text { Rata-rata } \\
\text { nilai }\end{array}$ & Persentase & Kategori \\
\hline 26 & 4,5 & $90,00 \%$ & Sangat baik \\
\hline
\end{tabular}


Berdasarkan data hasil penilaian tingkat keterbacaan dari 26 peserta didik, dapat dilihat bahwa nilai rata-rata keseluruhan pernyataan mencapai 4,5 dengan persentase 90,00\%. Hal itu menunjukkan bahwa tingkat keterbacaan modul oleh peserta didik termasuk ke dalam kategori "sangat baik". Kemudian penilaian afektif dengan jumlah 26 peserta didik sebelum diberikan pembelajaran dengan modul ( didapatkan hasil sebagai berikut:

Tabel 9. Hasil Penilaian Afektif Peserta Didik

\begin{tabular}{lccc}
\hline No & Jenis Tes & Jumlah & Rata-rata \\
\hline 1 & Kelas tanpa modul & 1995 & 79,8 \\
\hline 2 & Kelas Eksperimen & 2620 & 104,8 \\
\hline
\end{tabular}

Nilai afektif diperoleh dengan menggunakan angket. Berdasarkan hasil rekapitulasi angket dapat disimpulkan bahwa terjadi peningkatan nilai afektif yang ditunjukkan dengan nilai postest lebih besar dari pada pretest. Jadi, modul yang dikembangkan efektif meningkatkan kesadaran dan pemahaman peserta didik. Hasil penilaian dapat diketahui bahwa keseluruhan peserta didik memiliki nilai skor maximum sebesar 2.600 dengan 26 peserta didk. Untuk skor maximum penilaian afektif pada peserta didik 125. Pada penelitian ini nilai kelas eksperimen yaitu 2.744 dengan rata-rata 105,5 sedangkan pada kelas tanpa modul jumlah skor keseluruhan 1.981 dengan nilai rat-rata sebesar 76,19. Dengan demikian dapat disimpulkan bahwa pada kelas eksperimen peserta didik mengalami peningkatan dalam penilaian afektif masingmasing peserta didik

\section{PEMBAHASAN}

Bahan ajar bermakna untuk guru maupun peserta didik dalam proses pembelajaran. Tanpa panduan ajar akan sulit bagi guru untuk menambah efektivitas pembelajaran. Bahan ajar yang telah dibuat tentang berorientasi literasi sain memberikan manfaat yang banyak bagi peserta didik maupun bagi guru mata pelajaran yang ada disekolah, dengan mengusung literasi sains sesuai dengan kurikulum 13 yang saat ini mencanangkan adanya literasi sains. Sya'ban (2016:67) "berpendapat bahwa literasi sains adalah kemampuan peserta didik mengenal konsep, memahami, menjelaskan, mengkomunikasikan sains, menerapkan sains di kehidupan sehari-hari baik yang berada di kelas, madrasah dan lingkungan sekitar tempat tinggal untuk memecahkan persoalan keseharian yang berkaitan dengan materi yang telah dipelajari, sehingga mempunyai sikap positif dan kepekaan yang baik terhadap diri dan lingkungan (interaksi)".

Peningkatan literasi sains saat ini sangat diperlukan. Hasil dari validasi ahli media, desain, dan keterbacaan bahwa modul literasi sains yang dibuat memperoleh nilai skor dengan katagori sangat layak digunakan oleh guru maupun peserta didik. Hasil tersebut peningkatan nilai afektif pada peserta didik meningkat sekitar ratarata 104,5 \% dengan katagori tinggi atau mempunyai peningkatan dengan nilai rata-rata $\mathrm{B}$.

\section{KESIMPULAN}

Proses pengembangan dihasilakan produk berupa modul biologi yang berorientasi literasi sains. Secara fisik, modul berbentuk bahan ajar 
cetak yang berisi materi tentang komponen ekosistem yang berorientasi literasi sains yang relevan dengan materi secara lebih spesifik, disertai gambar dan penjelasan, serta tampilan yang dibuat semenarik mungkin untuk menimbulkan daya tarik bagi peserta didik untuk mempelajarinya, baik secara mandiri maupun secara berkelompok, Berdasarkan analisis data hasil pembelajaran peserta didik, diketahui bahwa afektif peserta didik mengalami peningkatan, antara sebelum menggunakan modul biologi dengan setelah menggunakan modul biologi yang dikembangkan.

\section{DAFTAR RUJUKAN}

Murat, Genc, 2015. The Effect of Scientific Studies on Students' Scientific Literacy and Attitude. Students" Scientific Literacy and Attitude. Vol 34 No 1 Hal 141-152 ISSN: 1300302X. Arastirma: Ondokuz Mayis University. Halaman 143.

Nisa, Ana Fitrotun. 2014. Pengembangan Modul Perubahan Kenampakan pada Bumi dan Benda Langit Berbasis Integrasi Islam-Sains Sebagai Sumber Belajar Mandiri Peserta Didik Kelas IV Madrasah Ibtidaiyah. Tesis Program Pascasarjana. Yogyakarta: UIN Sunan Kalijaga.

Prastowo, Andi. 2012. Pengembangan Sumber Belajar. Yogyakarta: Pedagodia.

Sawitri, Dita Widiyanti, Wisanti, dan Reni Ambarwati. 2014. Pengembangan Modul Keanekaragaman Hayati Berbasis Pendekatan Saintifik untuk Siswa Kelas X SMA. Bioedu. Vol.3 No.3 Agustus 2014. ISSN: 2302-9528. http://ejournal.unesa.ac.id/index.php/bi oedu. Halaman 411.

Sya'ban, Muhammad Fuad, dan Insih Wilujeng. 2016. Pengembangan SSP Zat dan Energi Berbasis Keunggulan Lokal untuk Meningkatkan Literasi Sains dan Kepedulian Lingkungan. Jurnal Inovasi Pendidikan IPA. Vol..2 No.1. ISSN 2406-9205. Yogyakarta:
Universitas Negeri Yogyakarta.

Halaman 67.

Yuliati, Yuyu. 2017. Literasi Sains dalam Pembelajaran IPA. Jurnal Cakrawala Pendas. Vol.3 No.2. ISSN 2442-7470. Majalengka: Universitas Majalengka. Halaman 22. 